\title{
Strategi Komunikasi untuk Meraih the Best Branch Service Excellent pada Bank Mandiri Jakarta Cikini
}

\author{
Nur Kholisoh ${ }^{1}$ dan Putri Rizky Priamsari ${ }^{2}$ \\ ${ }^{1,2}$ Magister Ilmu Komunikasi Universitas Mercu Buana \\ Jl. Meruya Selatan No. 1 Kembangan, Jakarta Barat - Indonesia \\ Corresponding author: kholisoh.nur@gmail.com
}

\begin{abstract}
As a service company, the Bank continues to strive to provide excellent service to all customers. In the framework of this, the management annually gives awards to the best of its branches. Bank Mandiri Cabang Jakarta Cikini previously never managed to become a branch with the best service, but in 2016, Bank Mandiri, Jakarta Cikini managed to obtain the title as Best Branch in Service Excellent. The research was initially want to know what communication strategy adopted by the Service Quality Officer (SQO) is the person responsible for the service division at Bank Mandiri, to bring Branch Cikini be the best. It turned out that there is a process of knowledge sharing undertaken by SQO through various activities involving the entire front liners which will be judged to be the best branch. The type of activity that is raised in this study there are four types, namely ESAs, Egrade, Cikini Academy, and Tracking. Knowledge discussed tasit divided into knowledge and explicit knowledge in the SECI models of Nanako and Takeuchi. Various activities have been proven to provide motivation and a stock of knowledge to all employees could face prosesn front liners for votes to become the best branch.
\end{abstract}

Keywords: knowledge sharing, knowledge tasit, explicit knowledge, banking services

\begin{abstract}
Abstrak
Sebagai perusahaan jasa, Bank Mandiri terus berupaya untuk dapat memberikan pelayanan yang prima kepada seluruh nasabahnya. Dalam rangka hal tersebut, manajemen setiap tahun memberikan penghargaan kepada cabangnya yang terbaik. Bank Mandiri Cabang Jakarta Cikini sebelumnya tidak pernah berhasil menjadi cabang dengan pelayanan terbaik, namun pada tahun 2016 Cabang Jakarta Cikini berhasil memperoleh predikat sebagai the Best Branch in Service Excellent. Penelitian ini ingin mengetahui strategi komunikasi apa yang diambil oleh Service Quality Officer (SQO) yaitu orang yang bertanggung jawab pada divisi pelayanan di Bank Mandiri, sampai membawa Cabang Cikini menjadi yang terbaik. Diketahui ada proses knowledge sharing yang dilakukan oleh SQO melalui berbagai kegiatan yang melibatkan seluruh frontliners untuk menjadi cabang terbaik. Jenis kegiatan yang diangkat pada penelitian ini ada empat jenis, yaitu Esas, Egrade, Cikini Academy, dan Tracking. Pengetahuan yang dibahas terbagi menjadi pengetahuan tasit dan pengetahuan eksplisit dalam model SECI dari Nanako dan Takeuchi. Berbagai kegiatan ini terbukti mampu memberikan motivasi dan bekal pengetahuan kepada seluruh pegawai frontliners untuk bisa menghadapi prosesn penilaian untuk menjadi cabang terbaik.
\end{abstract}

Kata Kunci : Knowledge sharing, Pengetahuan tasit, [engetahuan eksplisit, Pelayanan perbankan

Copyright @ 2018 Ikatan Sarjana Komunikasi Indonesia. All rights reserved

\section{PENDAHULUAN}

Penelitian ini berangkat dari pemahaman bahwa semua bank memiliki produk yang sama. Satu bank dengan bank yang lain sama-sama memiliki produk tabungan, produk deposito, kartu kredit, KPR, pinjaman, dan berbagai produk keuangan lainnya. Hal yang membedakan antara satu bank dengan lainnya adalah pelayanannya seperti bagaimana bank menyampaikan produknya kepada konsumen, menghadirkan kualitas layananan yang prima dan menciptakan loyalitas dari konsumen. 
Bank Mandiri memiliki prestasi tersendiri dalam hal pencapaian kualitas layanan yang prima. Berdasarkan hasil survey dari Marketing Research Indonesia (MRI) yang dikuti oleh lebih dari 10 bank, Bank Mandiri berhasil mendapat predikat sebagai The Best Bank in Service Excellence selama 9 tahun berturut-turut, mengalahkan pesainganya: BCA, BNI, BRI dan BTN. Penghargaan itu menjadi bahan kompetisi di antara perusahaan perbankan. Masing-masing bank memberikan layanan prima dalam pemenuhan kebutuhan keuangan nasabah. Hal ini menjadi salah satu latar belakang pemilihan Bank Mandiri sebagai lokasi penelitian ini. Dalam penilaian untuk menentukan bank dengan pelayanan terbaik, Bank Mandiri juga melakukan penilaian intern kepada cabang-cabangnya yang tersebar di seluruh Indonesia dan masih menggunakan MRI sebagai surveyornya. Survei terakhir yang dilakukan oleh MRI, menetapkan Bank Mandiri Cabang Jakarta Cikini sebagai cabang terbaik pertama di seluruh cabang Bank Mandiri di Indonesia. Untuk inilah penelitian ini menjadi hal penting untuk mengetahui strategi apa yang diambil oleh cabang tersebut sehingga mampu menjadi yang terbaik.

Berbicara mengenai standar pelayanan, seluruh cabang Bank Mandiri memiliki standar layanan yang sama, termasuk komponen penilaiannya, yaitu : customer service, teller, security, operator telepon, layanan ATM dan layanan call center Bank Mandiri. Mengingat adanya standar yang sama, maka menjadi suatu pertanyaan bagaimana Cabang Jakarta Cikini mampu menjadi yang terbaik pada skala nasional.

Di Bank Mandiri ada divisi khusus yang memang menangani di bidang pelayanan, pegawai yang bertanggung jawab pada divisi itu disebut dengan Service Quality Officer (SQO (Service Quality Officer). Bank Mandiri memiliki 12 region di seluruh Indonesia, masing-masing region memiliki SQO (Service Quality Officer) regionnya sendiri, dan membawahi beberapa area. Di masing-masing area ini terdapat yang namanya SQO (Service Quality Officer) Area, yang membawahi banyak cabang. Bank Mandiri Jakarta Cikini masuk dalam Region 4, Area Cikini, dengan SQO (Service Quality Officer) Area yang membawahi 21 cabang didalamnya. Dalam memotivasi jajaran pegawai di Cabang Jakarta Cikini tersebut, SQO (Service Quality Officer) menggunakan konsep knowledge sharing. Dalam mensosialisasikan standar pelayanan yang ditetapkan menejemen, melatih konsistensi pegawai dalam bekerja, dan pada akhirnya memotivasi untuk menjadi cabang terbaik di tahun 2016. Kegiatan knowledge sharing yang diterapkan pada cabang ini terdapat lebih dari satu macam kegiatan, diperoleh sedikitnya empat jenis kegiatan knowledge sharing yang diterapkan oleh SQO (Service Quality Officer) di cabang ini untuk meningkatkan kemampuan dan ajang memotivasi seluruh pegawai agar dapat memeberikan effort terbaik dalam pencapaian tujuan organisasi.

Empat kegiatan yang berhasil peneliti peroleh dari informan adalah: Esas, Egrade, Cikini Academy, dan Etrack. Keempatnya merupakan rangkaian knowledge sharing yang dilakukan oleh SQO (Service Quality Officer) dalam menginternalisasi pengetahuan terkait standar layanan kepada seluruh pegawai cabang tersebut. Tercapainya sebuah prestasi oleh suatu organisasi yang telah lama tidak menghasilkan prestasi, tidak lepas dari motivasi yang mendorong selurung anggota organisasi untuk dapat memberikan kontribusi yang positif. Kaitannya dengan tujuan sebuah organisasi, motivasi memegang peranan yang penting, untuk itu dalam rangka mendorong motivasi seringkali dibutuhkan strategi komunikasi yang mendukung. Melihat pola komunikasi yang demikian, dalam kaitannya pencapaian prestasi dari Bank Mandiri Cabang Jakarta Cikini, maka pertanyaan penelitiannya sebagai berikut : Bagaimana strategi komunikasi Service Quality Officer dengan frontliners melalui knowledge sharing dalam meraih $1^{\text {st }}$ best branch service excellent di tahun 2016 ?

\section{KERANGKA TEORITIS}


Strategi adalah cara atau taktik untuk menyelesaikan sesuatu (Simanjuntak, 2003). Definisi strategi yang lebih komprehensif adalah perencanaan dan manajemen untuk mencapai suatu tujuan. Namun untuk mencapai tujuan tersebut, strategi tidak berfungsi sebagai peta jalan yang hanya menunjukan arah saja, tetapi harus menunjukan bagaiamana taktik operasionalnya (Uchyana, 2006). Strategi sering didefinisikan sebagai perncanaan dan alokasi sumberdaya yang sengaja dibuat oelh sebuah organisasi untuk memposisikan dirinya agar lebih menguntungkan dibandingkan posisi para pesaing yang bergerak dalam kegiatan yang sama (Kaplan dan Norton dalam Sobirin, 2007).

Berdasarkan tiga definisi dari strategi di atas, maka strategi adalah alat manajemen yang dirancang oleh organisasi untuk mencapai tujuan jangka panjang organisasi sebagai bagian dari pencapaian visi dan misi organisasi. Oleh karenanya, untuk mencapai tujuan organisasi tersebut ada dua egiatan utama yang harus dilakukan pleh organisasi yaitu formulasi strategi dan implmentasi strategi (Sobirin , 2007).

Sementara itu, komunikasi berasal dari Bahasa latin yaitu Communis yang berarti sama (common). Artinya ketika melakukan komunikasi dengan orang lain berarti kita sedang menyampaikan pesan dan berusaha agar ada kesamaan makna terhadap pesan tersebut, dan dalam rangka mengoptimalkan peran komunikasi diperlukan pemahaman cara-cara berkomunikasi. Karl John R. Wenburg dan William W Wilmot, Kenneth K Sereno dan Edward M Bodaken dalam Deddy Mulyana (2009) menyatakan, setidaknya ada tiga kerangkan pemahaman mengenai komunikasi, yakni komunikasi sebagai tindakan satu arah, komunikasi sebagai interaksi dan komunikasi sebagai transaksi.

Pemahaman pertama, definisi komunikasi sebagai tindakan satu arah dikemukakan oleh Harold laswell yaitu "Who says what in which channel to whom eith what effect", berasarkan definisi tersebut terdapat lima unsure komunikasi yang saling bergantung satu sama lain, yaitu: Pertama, sumber (source) adalah pihak (individu, organisasi, kelompok, negara) yang berinisiatif atau mempunyai kebutuhan untuk berkomunikasi. Kedua, pesan, yaitu apa yang dikomunikasi kan oleh sumber kapada penerima. Ketiga, saluran atau media, yakni alat atau wahan yang digunakan sumber untuk menyampaikan pesannya kepada penerima. Saluran dapat berupa saluran verbal maupun non verbal, atau dalam bentuk cara penyajian pesan apakah dalam bentuk tatap muka, melalui media cetak, elektronik, dsb. Sumber informasi dapat memilih media yang tepatdalam menyampaikan pesannya. Keempat, penerima pesan (receiver) dari sumber. Penerima pesan menerjemahkan atau menafsirkan seperangkat simbol verbal atau non verbalyang ia terima menjadi gagasan yang dapat ia pahami (proses ini disebut penyandian bail/ decoding). Kelima, efek yaitu apa yang terjadi kepada penerima pesan setelah pesan itu diterima.

Pemahaman kedua, komunikasi sebagai interaksi - tindakan saling mempengaruhi. Untuk memahami komunikasi sebagai interaksi adalah adanaya aksi reaksi atau sebab akibat yang arahnya bergantian. Unsure yang ditambahkan dalam pemahaman ini adalahadanya proses timbale balik antara pemberi pesan dan penerima pesan kemudian digunakan oleh pemberi pesan untuk mengukur efektivitas pesan yang disampaikan, apakah pesan dapat dimengerti dapat diterima, menghadapi kendala dan sebagainya. Sehingga melalui umpan balik tersebut pemberi pesan dapat memperbaiki pesan yang akan disampaikan kepada penerima pesan, agar pesan yang diterima sesuai dengan tujuan yang diinginkan.

Pemaham ketiga komunikasi sebagai transaksi. Komunikasi dipandang sebagai proses dinamis, karena memungkinkan pemberi pesan mengetahui secara langsung respon terhadap pesan (verbal maupun non verbal). Komunikasi merupakan salah satu usahauntuk memperoleh makna. 
Komunikasi dipandang sebagai sebuah proses karena dalam kegiatan berkomunikasi ada tindakan, perubahan pertukaran dan perpindahan, serta terdapat kontinuitas dalam setiap unsurnya.

Menurut Lawrance D. Brennan, komunikasi internal adalah "interchange of ideas among the structure (organization) and interchange of ideas horizontally and vertically within the firm which gets work done (operation and management)." (Pertukaran gagasan di antara para administrator dan karyawan dalam suatu perusahaan atau ajwatan yang menyebabkan terwujudnya perusahaan atau jawatan tersebut lengkap dengan strukturnya yang khas (organisasi) dan pertukaran gagasan secara horizontal dan vertikal di dalam perusahaan atau jawatan yang menyebabkan pekerjaan berlangsung (operasi dan manajemen). (Effendy, 1990:122). Dimensi Komunikasi Internal terdiri dari komunikasi vertikal dan komunikasi horizontal, dan komunikasi diagonal.

Komunikasi Vertikal terbagi menjadi dua yaitu komunikasi ke atas dan komunikasi ke bawah. Komunikasi ke atas adalah komunikasi yang berlangsung dari bawahan ke atasan, atau dari suatu organisasi yang lebih rendah dengan satuan organisasi yang lebih tinggi.(Wursanto, 2005:161). Semua pegawai dalam organisasi, kecuali mungkin mereka yang menduduki posisi puncak, mungkin berkomunikasi ke atas yaitu, setiap bawahan mempunyai alasan yang baik atau meminta informasi dari atau memberin informasi kepada seorang yang otoritasnya lebih tinggi daripada dia.(Pace \& Faules, 2010: 189).

Sedangkan komunikasi ke bawah adalah komunikasi yang berlangsung dari pimpinan kepada bawahan. Komunikasi ke bawah mengalir dari pimpinan kepada para bawahan, dari tingkat manajemen puncak ke manajemen menengah, ke manajemen tingkat bawah terus mengalir kepada para pekerja, melalui secara hierarki (Wursanto , 2005: 161-162). Komunikasi kebawah dalam organisasi berarti bahwa informasi mengalir dari jabatan berotoritas lebih tinggi kepada mereka yang berotoritas lebih rendah. Biasanya kita beranggapan bahwa informasi bergerak dari manajemen kepada para pegawai; namun dalam organisasi kebanyakan hubungan ada pada kelompok manajemen (Davis, 1967). .(Pace \& Faules, 2010: 184).

Dalam komunikasi vertikal, pimpinan memeberikan instruksi-instruksi, petunjuk-petunjuk, informasi-informasi, penjelasan-penjelasan, dan lain-lain kepada bawahannya. Sedangkan bawahan memberikan laporan-laporan, saran-saran, pengaduan-pengaduan dan sebagainya kepada pimpinan (Effendy, 1990:123).

Komunikasi Horizontal adalah komunikasi secara mendatar, antara anggota staf dengan anggota staf, karyawan dengan karyawan, dan sebagainya. Komunikasi horizontal biasanya tidak formal karena terjadi dengan orang yang memiliki tingkatan yang sama (Effendy, 1990:124). Pesan dalam komunikasi horizontal biasanya berhubungan dengan tugas-tugas atau tujuan kemanusiaan, seperti koordinasi, pemecahan masalah, penyelesaian konflik, saling memberikan informasi dan mengembangangkan sokongan interpersonal.

Bentuk dari komunikasi horizontal yang sering terjadi yaitu, rapat-rapat komite, interaksi pada jam istirahat, percakapan telepon, dan aktivitas sosial. Dalam komunikasi sosial sering kali terjadi masalah, yaitu jika ada desas-desus akan cepat sekali menyebar dan menjalar karena komunikasi horizontal bias dilakukan di saat jam istirahat atau santai. Dan yang didesas-desuskan sering kali mengenai hal-hal yang menyangkut pekerjaan atau tindakan pimpinan yang merugikan mereka.

Komunikasi diagonal terbagi menjadi dua yaitu, diagonal ke atas dan diagonal ke bawah. Komunikasi diagonal ke atas adalah komunikasi yang berlangsung antara pejabat yang lebih rendah (bawahan) dengan pejabat atau pimpinan yang lebih tinggi. Sedangkan komunikasi diagonal ke bawah adalah komunikasi yang berlangsung dari seorang pimpinan dengan pejabat atau pimpinan yang lebih rendah. Jadi komunikasi diagonal (ke atas maupun ke bawah) adalah komunikasi antara 
pejabat-pejabat atau unit-unit yang berbeda tingkatan (level) dan wewenangnya baik yang secara fugsional ada hubungannya maupun secara fungsional tidak ada hubungannya (Wursanto , 2005: 163).

Komunikasi internal meliputi berbagai cara yang dapat diklasifikasikan menjadi dua jenis,

yaitu Komunikasi persona (personal communication) dan komunikasi kelompok (group communication).

Komunikasi persona terbagi menjadi dua yaitu komukasi tatap muka dan komunikasi bermedia. Komunikasi tatap muka terjadi karena berlangsung secara dialogis sambil saling menatap sehingga terjadi kontak pribadi (personal contact). Sedangkan komunikasi bermedia adalah komunikasi dengan menggunakan alat, misalnya telepon atau memorandum. Karena melalui alat, maka antara kedua orang tersebut tidak terdapat kontak pribadi.

Komunikasi kelompok (group communication) adalah komunikasi antara seseorang dengan kelompok orang dalam situasi tatap muka. Kelompok ini bisa kecil dan besar tergantung berapa jumlah orang yang termasuk dalam kelompok tersebut. Oleh karena itu, dalam komunikasi kelompok dibedakan antara komunikasi kelompok kecil dan komunikasi kelompok besar (Effendy, 1990:125-126).

Komunikasi kelompok kecil adalah suatu kumpulan individu yang dapat mempengaruhi satu sama lain, memperoleh beberapa kepuasan satu sama lain, berinteraksi untuk beberapa tujuan, mengambil peranan, terikat satu sama lain dan berkomunikasi tatap muka. Jika salah satu komponen ini hilang individu yang terlibat tidaklah berkomunikasi dalam kelompok kecil. Menurut Robert F. Bales dalam bukunya, Interaction Process Analysis, mendefinisikan kelompok kecil sebagai sejumlah orang yang terlibat dalam interaksi satu sama lain dalam suatu pertemuan yang bersifat tatap muka (face-to-face meeting) di mana setiap peserta mendapat kesan atau penglihatan antara satu sama lainnya yang cukup kentara, sehingga dia-baik pada saat timbulnya pertanyaan maupun sesudahnyadapat memberikat tanggapan kepada masing-masing sebagai perseorangan (Effendy, 1990: 127). Kelompok kecil sekumpulan orang yang biasanya kurang dari tujuh orang, berinteraksi dalam jangka waktu agak lama dan memiliki kepentingan yang sama yang terbentuk dalam satu tujuan yang telah disepakati. Contoh komunikasi kelompok kecil yaitu seminar, ceramah, diskusi, penataran dan sebagainya.

Menurut Effendy (1990:77) Komunikasi kelompok besar adalah komunikasi yang ditujukan kepada afeksi (perasaan) komunikan dan prosesnya berlangsung secara linear. Jadi dapat dikatakan bahwa dalam komunikasi kelompok besar kontak pribadi sulit dilakukan. Komunikator dalam komunikasi ini cenderung hanya membakar emosi komunikannya dan tanggapannya bersifat emosional. Contoh komunikasi kelompok besar adalah kongres dari sebiah organisasi (bersifat formal) dan kampanye di lapangan (bersifat non formal).

Davenport dan Prusak (1998) menyebut pengetahuan sebagai pengalaman, nilai-nilai, konteks dan wawasan yang tercampur sehingga menyediakan sebuah kerangka kerja untuk mengevaluasi dan menghubungkan pengalaman-pengalaman dan informasi baru. Kedua peneliti ini menemukan bahwa di dalam organisasi pengetahuan kerap menjadi artefak yang melekat seperti dokumen, video, audio atau penyimpanan di dalam rutinitas, proses, praktek, dan norma-norma perusahaan. Mereka juga melihat bahwa pengetahuan akan bernilai apabila ada tambahan konteks, budaya, pengalaman, dan interpretasi dari manusia. Nonaka (1994) melihat pengetahuan dalam arti yang lebih spesifik. Pengguna pengetahuan harus mengerti dan melihat pengalaman dengan konteks yang ada, kondisi dan pengaruh yang melingkupi, sehingga pengetahuan dihasilkan dan berarti untuk mereka. Nonaka 
dan Takeuchi (1995) menggambarkan dua tipe pengetahuan yaitu tacit knowledge dan explicit knowledge.

Tacit knowledge adalah pemahaman yang ada di dalam pikiran pemilik pengetahuan dan tidak secara langsung dapat dimunculkan dalam bentuk data atau representasi pengetahuan sehingga kerap disebut pengetahuan yang tidak terstruktur. Explicit knowledge yaitu pengetahuan yang secara langsung berbentuk pengetahuan dan umumnya disebut sebagai pengetahuan terstruktur. Sehingga, pengetahuan adalah gabungan antara kedua pengetahuan tersebut.

\section{Knowledge Sharing}

Nonaka dan Takeuchi (1995) menawarkan empat model pembentukan dan knowledge sharing atau yang dikenal sebagai model SECI (Socialization, Externalization, Combination, Internalization) . Keempatnya adalah :

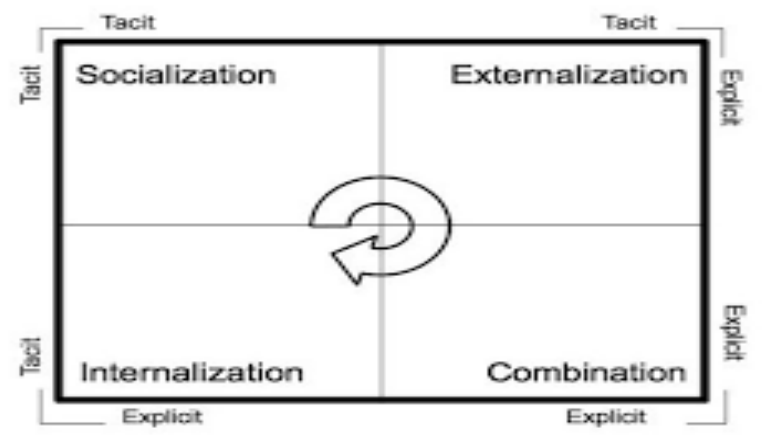

Gambar 1. SECI Model Sumber : Nonaka dan Takeuchi (1995)

Socialization adalah proses knowledge sharing dan membuat tacit knowledge sebagai model mental dan keterampilan teknis. Tacit knowledge dapat diperoleh melalui observasi, imitasi, dan praktek. Externalization adalah proses artikulasi tacit knowledge dalam bentuk konsep eksplisit dalam bentuk metafora, analogis, hipotesis, atau model.

Combination adalah proses konsep sistemis ke dalam sistem pengetahuan dengan menggabungkan expilicit knowledge yang berbeda. Explicit knowledge dipindah melalui media seperti dokumen, pertemuan, email atau percakapan telepon. Kategorisasi pengetahuan ini akan memunculkan pengetahuan baru. Internalization adalah proses mengubah explicit knowledge menjadi tacit knowledge dan dekat dengan konsep pengalaman karena mengerjakan atau dapat disebut learning by doing.

\section{METODE PENELITIAN}

Penelitian ini didesain sebagai penelitian studi kasus. Penelitian studi kasus adalah suatu penelitian kualitatif yang berusaha menemukan makna, menyelidiki proses, dan memperoleh pengertian dan pemahaman yang mendasari individu, kelompok, atau situasi. Menurut Smith, studi kasus dapat menjadi berbeda dari bentuk-bentuk penelitian kualitatif lain oleh fakta bahwa studi ini berfokus pada satu unit tanggal atau sistem terbatas. (Emzir 2010),

Kasus yang dibahas dalam penelitian ini adalah berhasilnya Bank Mandiri Cabang Jakarta Cikini menjadi cabang dengan pelayanan terbaik pada tahun 2015, hal ini menarik untuk dicari tahu karena sebelumnya cabang ini hanya berhasil menduduki maksimal peringkat ke-6 cabang terbaik, dan tahun 2015 menjadi yang terbaik se-Indonesia. 
Untuk memulai studi kasus peneliti mengidentifikasi masalah atau pertanyaan yang akan diteliti dan mengembangkan suatu rasional untuk mengapa studi kasus merupakan metode yang sesuai untuk digunakan dalam studi ini. Masalah atau pertanyaan yang dirangkai melalui pengalaman, observasi,dan tinjauan peneliti yang relevan.

Teknik pengumpulan data dilakukan untuk menjaring data dari satuan-satuan pengamatan. Data-data yang digunakan dalam penelitian ini terdiri dari data primer dan data sekunder. Data tersebut dijabarkan sebgai berikut: data primer adalah data utama yang akan digunakan dalam proses penelitian. Sumber data yang digunakan dalam penelitian ini ialah dengan menggunakan teknik wawancara, yakni dipergunakan untuk memperoleh informasi dari informan yang merupakan bukti dalam lapangan yang merupakan bagian representative dari populasi yang dimaksudkan untuk memperoleh data tentang permasalahan yang berhubungan dengan mereka.

Informan yang dipilah dalam penelitian ini ada empat informan, yaitu, Bapak Arif Nugroho selaku SQO (Service Quality Officer), Bapak Fajar Arafandi selaku Customer Service, Bapak Yoyo Turmono selaku Security, dan Ibu Yuwinda selaku Teller. Pemilihan Bapak Arif sebagai informan karena strategi beliau yang ingin diketahui oleh peneliti, sehingga mampu membawa Cabang Cikini menjadi cabang yang terbaik pada tahun 2016 lalu. Pemilihan Bapak Fajar, Bapak Yoyo, dan Ibu Yuwinda, informan ini dapat mewakili seluruh elemen frontliners yang dibutuhkan oleh peneliti dari Customer Service, Security, dan Teller. Ketiga frontliners ini bertugas di Cabang Cikini selama penyelenggaraan proses pemilihan cabang terbaik saat itu. Maka ke empat informan ini dianggap layak oleh peneliti untuk dapat digali informasi serta data-data terkait penelitian ini.

Analisis dokumentasi dilakukan untuk mengumpulkan data yang bersumber dari arsip dan dokumen lainnya yang ada dalam organisasi tersebut. Menurut Arikunto (2006: 132), teknik dokumentasi yaitu mencari data mengenai hal atau variable yang berupa catatan,buku,surat,notulen meeting, agenda dan lain-lain. Sumber data sekunder yang digunakan dalam penelitian ini ialah dengan mencari sumber-sumber kepustakaan yang relevan seperti buku, jurnal, website, diskusi bersama praktisi dan lain-lain.

Teknik analisis data adalah proses mencari dan menyusun secara sistematis data yang diperoleh dari hasil wawancara, catatan lapangan, dan dokumentasi, dengan cara mengorganisasikan data kedalam kategori, menjabarkan kedalam unit-unit , melakukan sintesa, menyusun kedalam pola, memilih mana yang penting dan yang akan dipelajari dan membuat kesimpuloan sehingga mudah dipahami oleh diri sendiri maupun orang lain (Sugiyono 2010)

Data penelitian ini merupakan data kualitatif yang didapatkan dari hasil wawancara, catatan lapangan, dan komentar peneliti. Untuk itu terdapat tiga alur kegiatan yang dapat dilakukan secara bersamaan yaitu : Reduksi data, suatu proses pemilihan, pemusatan perhatian pada penyederhanaan, pengabstrakan dan transformasi data kasar yang muncul dari catatan tertulis dilapangan. Data kualitatif disederhanakan dan di transformasikan dengan aneka macam cara, aturan lain seleksi yang ketat, ringkasan atau uraian singkat, penggolongan dalam suatu pola yang lebih luas.

Penyajian data,yaitu susunan sekumpulan informasi yang memungkinkan penarikan kesimpulan dan pengambilan tindakan.

\section{Penarikan kesimpulan atau verifikasi,}

yaitu berupa tinjauan atau pemikiran kembali pada catatan lapangan, yang mungkin berlangsung sekilas atau malah dilakukan secara seksama dan memakan waktu lama, serta bertukar pikirandengan subjek penelitian untuk mengembangkan inter subjektivitas. Makna yang muncul dari data harus diuji 
kebenarannya, kekokohannya, dan kecocokan nya sehingga membentuk validitasnya (Miles \& Huberman 1992).

Setelah proses penelitian, data yang ada kemudian dilakukan verifikasi untuk pembuktian kebenarannya, tekniknya dapat dengan mengunjungi kembali lokasi penelitian, dan melakukan uji kebenaran dan memvaliditas kebenaran hasil penelitian.

Teknik Pemeriksaan Keabsahan Data. Teknik pemeriksa keabsahan data pada penelitian ini menggunakan teknik triangulasi (gabungan) tenik ini mengutamakan efektivitas dari hasil yang diinginkan. Oleh karena itu, triangulasi dilakukan dengan menguji apakah hasil proses dari hasil metode yang digunakan sudah berjalan dengan baik, peneliti menggunakan observasi (pengamatan) untuk mengumpulkan data dengan menggunakan sumber primer dan sekunder.

Menurut Moleong (2010), triangulasi adalah teknik pemeriksaan keabsahan data yang memanfaatkan sesuatu yang lain. Diluar data untuk keperluan pengecekan atau sebagai pembanding terhadap data itu. Teknik triangulasi yang paling banyak digunakan ialah pemeriksaan melalui sumber lainnya.

\section{HASIL PENELITIAN}

Selama masa penilaian di tahun 2015, Bank Mandiri Cabang Jakarta Cikini berbenah diri di bawah komando SQO (Service Quality Officer), Bapak Arif dengan melakukan berbagai kegiatan yang bertujuan untuk membagikan pengetahuan terkait standar layanan, dan juga untuk menginternalisasikan pengetahuan tersebut kepada seluruh cabang di Area nya termasuk Bank Mandiri Cabang Jakarta Cikini. Berbagai kegiatan yang dimaksud akan dipaparkan pada sub bab 4.2 ini dan akan dibahas lebih lanjut kaitan nya dengan komunikasi dan teori yang diambil pada sub bab 4.3 selanjutnya. Kegiatan knowledge sharing yang berhasil peneliti dapat pada masa penelitian adalah Esas, Egrade, Cikini Academy dan Tracking.

Esas ialah Evaluation Self Assesment, yaitu metode assessment yang dilakukan dengan mengumpulkan seluruh pegawai cabang yang dikualifikasikan berdasarkan jabatannya, sehingga ada kelompok esas security, ada kelompok esas teller, dan esas customer service. Mengapa dibedakan, karena standar layanan masing-masing jabatan berbeda, tingkat product knowledge yang sesuai dengan masing-masing jabatan juga tidak sama. Tentunya pengetahuan yang ingin dibagikan adalah pengetahuan yang memang nanti nya akan bermanfaat dalam bidang pekerjaan nya masing-masing.

Esas dilakukan oleh SQO (Service Quality Officer) rutin sekali dalam satu bulan. Mekanisme nya, SQO (Service Quality Officer) mengundang seluruh pegawai untuk berkumpul di ruang rapat Area Cikini, dalam waktu yang sudah ditentukan menjawab 25-30 soal pilihan ganda yang ditayangkan melalui proyektor. Selanjutnya seluruh pegawai mengisi lembar jawab yang telah disediakan. Soal-soal esas sendiri beragam, pastinya ada pengetahuan mengenai standar layanan dan product knowledge. Ada nilai dari masing-masing pegawai, dan ada sistem remedial bagi yang tidak memenuhi standar nilai. SQO (Service Quality Officer) sendiri selalu mengirimkan materi yang diangkat untuk soal-soal esas sekurang-kurang nya 2 hari sebelum esas diselenggarakan. Pelayanan yang ingin diberikan oleh Bank Mandiri tidak hanya sekedar keramahan namun juga dengan menghadirkan petugas-petugas bank yang mumpuni di setiap bidangnya.

Pada metode esas, SQO (Service Quality Officer) menggunakan nya sebagai ajang knowledge sharing yang memberikan pengetahuan lebih mendalam kepada pegawai, karena pasca esas SQO (Service Quality Officer) memberikan penjelasan mengenai soal-soal yang dianggap sulit atau membingungkan oleh para pegawai. Bagi pegawai senior biasanya ikut membantu dalam berbagi 
pengalaman terkait soal yang dberikan. Hanya saja karena waktu yang digunakan ialah jam sesuai waktu kerja, dan dibagi menjadi tiga kategori terpisah berurutan (security, CS, Teller), maka waktu yang dugunakan sangat terbatas, sehingga pada saat esas kegiatan knowledge sharing tidak terlalu detail membahas berbagai hal.

Nantinya aka nada nilai yang keluar dari hasil Esas ini, dan nilai tersebut akan diinformasikan secara luas oleh Pak Arif agar semua pegawai tau berapa nilainya, knowledge sharing dalam metode Esas selain bermanfaat menambah pengetahuan pegawai juga menimbulkan motivasi dari para pegawai agar dapat menguasai materi yang akan di ujikan, hal ini berarti Bapak Arif tidak hanya mengedepankan pengetahuan yang wajib dikuasai namun membangun semangat dari setiap pegawai nya.

Untuk kegiatan knowledge sharing yang satu ini, tidak serempak dilakukan oleh seluruh pegawai seperti hal nya esas. Egrade atau Evaluation Grade ini dilakukan bertahap, frekwensi nya sendiri ialah satu kali dalam satu minggu. Mekanisme nya yaitu, SQO (Service Quality Officer) memanggil pegawai-pegawai senior sesuai dengan jabatan nya (security, CS, Teller) masing-masing satu orang. Satu perwakilan ini dilatih secara langsung dengan metode role play oleh SQO (Service Quality Officer), sampai dengan dikatakan sesuai dengan standar layanan yang ada (berdasarkan checklist yang telah ditentukan). Diakui bahwa berinteraksi dengan rekan sebaya atau setara (dalam hal ini satu jabatan, sehingga tidak lebih tinggi dari yang lain), akan lebih leluasa dan terbuka. Satu sama lain dapat memberikan masukan dan saran tanpa rasa sungkan, begitu pula dalam memberikan kritik yang sifatnya membangun. Hal ini yang coba didapatkan oleh SQO (Service Quality Officer), yaitu membuka peluang sharing sebesar-besarnya antar pegawai, agar pengalaman (pengetahuan tasit) yang berharga dapat diketahui oleh lebih banyak pegawai yang lain.

Pada kegiatan Egrade, masing-masing diberikan buku penilaian, sudah sampai pada grade mana. Setelah dirasa baik, maka SQO (Service Quality Officer) memanggil pegawai lain yang lebih junior dengan jumlah yang lebih banyak, dan menjadikan pegawai senior tersebut sebagai mentor. Kegiatan mentoring dari dan oleh pegawai ini terus berlanjut sampai dirasa seluruh pegawai telah memiliki kualitas mentor dalam kualitas pelayanannya. Sama seperti esas, bagi pegawai yang tidak lolos pada saat ujian egrade juga dilakukan kelas mentor ulang, sampai akhirnya lulus diujian naik grade menjadi mentor.

Seperti dibahas sebelumnya, dalam melakukan pelayanan terhadap nasabah diharapkan pegawai dapat lebih tulus dan tidak terkesan robotic, namun tetap berpegang pada standar layanan yang telah ditetapkan oleh manajemen. Untuk itulah perlu adanya checklist standar layanan bagi masing-masing pegawai, agar tidak 'lari' dari petunjuk teknis yang ada.

Salah satu yang menarik dari egrade ini adalah bagian hitung uang cepat. Teller diwajibkan mampu menghitung satu gepok uang kertas dalam waktu kurang dari 10detik, yang melebihi 10 detik belum dinyatakan lulus, dan belum bisa menjadi mentor,perlu adanya kompetisi agar muncul motivasi yang lebih dari setiap pegawai, tentunya kompetisi dalam hal yang positif membuat pegawai memberikan effort lebih dalam bekerja.

Kegiatan knowledge sharing yang juga diadakan oleh SQO (Service Quality Officer) adalah Cikini Academy. Mekanisme nya ialah, setiapdua kali sebulan pada hari kamis, SQO (Service Quality Officer) membuka Cikini Academy yang berlokasi di aula Area Cikini, mengundang seluruh pegawai pada jam setelah tutup pelayanan. Setelah dibuka oleh SQO (Service Quality Officer), acara diisi dengan refreshment produk dan standar layanaan (eksplisit knowledge), dilanjutkan dengan berbagi pengalaman serta Tanya jawab (tasit knowledge) . pembicara yang dihadirkan oleh Pak Arif juga tidak sembarangan, beliau mengundang pembicara dari kantor pusat yang memang mengusai betul 
materi yang akan dibahas. Selain itu, diadakan pula roleplay benar-benar di banking hall. Roleplay dilakukan oleh SQO (Service Quality Officer) sebagai nasabah, dan security, CS ,dan Teller benarbenar melayani nasabah. Roleplay dilakukan bergiliran antar pegawai antar cabang, bagi yang menonton diharap memberikan catatan feedback untuk rekan yang lain. Setelah semua selesai roleplay, masing-masing akan membacakan catatan feedback yang diperoleh. Karakteristik nasabah yang datang tentunya berbeda-beda, dan disinilah salah satu peran penting pengetahuan tasit. Dimana pengalaman dengan masalah-masalah yang variatif dapat dibantu dicarikan solusinya dalam kegiatan ini.

Setiap pegawai menyampaikan apa saja kendala yang kerap ditemui, dan yang lain memberikan saran dan masukan. Selain segi pelayanan, ajang ini juga digunakan untuk knowledge sharing untuk berbagai product knowledge, seperti update fitur dari berbagai produk yang dimiliki Bank Mandiri. Ajang ini sangat dimaksimalkan oleh seluruh pegawai dalam berbagi pengalaman, seperti bertemu dengan macam-macam karakter nasabah yang sering kali menyulitkan untuk dicari jalan keluarnya. Bahkan ada moment dimana, forum ini digunakan untuk tutorial menggunakan hijab yang sesuai dengan standar berpakaian seragam di Bank Mandiri, tak hanya hijab, makeup juga sering menjadi bahan sharing diforum ini.

Cikini Academy menjadi sebuah strategi yang dianggap paling efektif dalam konsep knowledge sharing. Ketika ahlinya dari sebuah produk datang, ahlinya dari standar layanan dihadirkan, maka terbuka forum bagi seluruh pegawai menanyakan hal-hal yang ingin diketahui, atau yang kurang jelas selama ini. Pak Arif menghadirkan mentor-mentor yang mampu memfasilitasi hal tersebut.

Terakhir dari knowledge sharing yang diangkat dalam penelitian ini ialah tracking. Pada metode ini SQO (Service Quality Officer) menjadi nasabah sebenarnya dan datang kecabang. Selain SQO (Service Quality Officer) sendiri, seringkali SQO (Service Quality Officer) menunjuk pegawai magang yang baru, untuk menjadi mystery shopper. Rekan-rekan SDP ialah pegawai Bank Mandiri yang akan melakukan On Job Training, yang merupakan cross dari wilayah lain. Sehingga tidak kenal dengan pegawai yang ada di cabang saat itu.

Metode ini dirasa efektif untuk mengetahui betul sejauh mana pegawai cabang melayani nasabah, karena pegawai tidak tahu bahwa layanan yang mereka berikan direkam dan diserahkan kepada SQO (Service Quality Officer). SQO (Service Quality Officer) dapat menilai, siapa saja yang sudah baik dalam memberikan layanan dan yang belum. Metode ini dapat dikatakan sebagai 'ujian', setelah berbagai proses knowledge sharing. Pegawai dapat dilihat sejauh mana pengetahuan itu dikuasai, dan pastinya konsistensi nya. SQO (Service Quality Officer) juga dapat mendapatkan feedback dari berbagai kegiatan knowledge sharing yang sudah diselenggarakan.

Knowledge sharing pada metode ini ialah ketika hasil tracking sudah keluar. Akan ada forum evaluasi yang diselenggarakan untuk saling memberikan kritik yang membangun dan perbaikan tentunya. Metode ini dirasa paling real diantara yang lain, karena pegawai benar-benar diberikan masukan dan saran berdasarkan praktik real.

Selain dilakukan oleh orang lain, Pak Arif juga rutin melakukan tracking ke cabang-cabang, kunci nya beliau selalu disiplin dan konsisten dalam melakukan tracking, karena menurutnya semakin banyak latihan pegawai akan semakin terbiasa melayani nasabah sesuai standar layanan yang sudah ditetapkan. Diakui Pak Arif, tracking bukan lah hal yang mudah, terkadang cabang yang dikunjungi memiliki antrian yang sangat panjang dan sangat menyita waktu, namun Pak Arif mengedepankan kedisiplinan termasuk pada diri sendiri untuk tetap melakukan tugas-tugasnya. 
Selanjutnya memasuki tataran teori SECI Model, penelitian ini akan mencoba mengupas Knowledge sharing yang diimplemetasikan melalui Esas, Egrade, Cluster Forum dan Tracking menggunakan model tersebut. Nonaka dan Hirakata sebagai penemu model ini, menganggap bahwa pengetahuan merupaka suatu hal yang dinamis dan dapat berubah bentuk antara tacit dan explicit. SECI Model ini memungkinkan organisasi untuk mengelola proses tersebut secara efektif. Model ini memuat empat langkah dalam proses nya, yaitu Socialization, Externalization, Combination, dan Internalization.

Socialization dapat diartikan men-sharing pengetahuan dari satu individu ke individu lain nya yang berupa tacit knowledge. Langkah ini muncul dari aktivitas berbagi dan menciptakan pengetahuan tacit melalui pengalaman langsung. Sebagai ilustrasi dari tacit knowledge, adalah ilmu memasak. Ketika seorang koki dalam tayangan televisi mengatakan untuk menambahakan gula atau garam secukup nya, maka kata 'secukupnya', adalah sebuah pengetahuan yang berdasarkan pada pengalaman tentang berapa banyak nya garam atau gula yang dibutuhkan untuk menghasilkan rasa yang pas. Socialization dalam praktiknya di lokasi penelitian, dalam kegiatan knowledge sharing dapat kita lihat pada kegiatan Cikini Academy.

Menciptakan kepuasan dan kenyamanan pada nasabah tidak melulu berdasarkan standar layanan yang telah disusun oleh manajemen. Sebagai contoh, dalam standar layanan, seorang customer service harus memberikan seluruh penjelasan terkait sebuah produk yang ingin nasabah gunakan, namun pada kenyataan nya, sering kali nasabah merasa standar layanan ini terlalu berteletele, lama dan memakan waktu. Ilmu atau pengetahuan terkait menghadapi berbagai macam karakter nasabah, tentunya tidak akan didapat tanpa adanya pengalaman, namun apabila harus mengalami dulu baru mengerti akan butuh waktu lama bagi seorang CS mampu menghadapi nasabah, karena nya ada proses socialization pada kegiatan Cikini Academy, yang fungsinya untuk berbagi pengetahuan berdasarkan pengalaman yang pernah dilalui oleh rekan kerja yang lain.

Knowledge sharing dalam tataran socialization, disebutkan acap kali terjadi diantara orang ke orang dalam sebuah percakapan atau diskusi. Berbagi pengetahuan yang sifatnya tacit knowledge, adalah hal yang sangat berpengaruh. Tacit knowledge yang tidak tertuang dalam ketentuan standar layanan menjadi samar dan meraba-raba, bagaimana sih baiknya menghadapi nasabah dengan masalah A atau masalah B dalam kondisi C atau D, dan sebagai nya, dan justru kiat-kiat yang diperoleh dari proses socialization menjadi salah satu solusi untuk memperkaya pengetahuan.

Selain dengan sesama pegawai, socialization juga kerap ditemui pada percakapan antara SQO (Service Quality Officer) dan pegawai, Bapak Arif memiliki ‘jam terbang’ yang lebih dibandingkan dengan pegawai yang ada, beliau sering kali memebrikan solusi dari permasalahan yang dihadapi pegawai bukan berdasarkan ketentuan tertulis, melainkan berdasarkan pengalaman nya, termasuk memberikan masukan dan saran agar masing-masing pegawai mampu mengeluarkan seluruh kemampuannya, untuk menjadi yang terbaik.

Karenanya, proses berbagi pengetahuan tacit to tacit ini berpengaruh pula pada langkah SECI Model selanjutnya. Tahapan selanjutnya pada SECI Model ialah Externalization. Secara lebih sederhana tahapan ini adalah bagaimana knowledge sharing yang terjadi ialah dari pengetahuan tacit menjadi explicit. Sebagai ilustrasi, ketika seorang koki yang memiliki pengalaman memasak berbagai jenis makanan membuat sebuah buku resep yang dapat dibaca oleh banyak orang yang juga ingin bisa memasak seperti diri nya. Tahapan ini adalah tahapan dimana pengetahuan yang umum nya tidak terstruktur, dibuat menjadi lebih sistematis sehingga dapat dipahami individu lain dengan mudah. Dalam rangkaian nya pada kegiatan knowledge sharing di kantor Cabang Cikini, tahapan externalization terlihat pada kegiatan egrade. 
Seperti telah diuraikan sebelumnya, kegiatan ini dilakukan bertahap pada seluruh pegawai, yang penguji nya juga adalah dari sesama pegawai. Pegawai yang lebih senior, atau yang memang memiliki pengetahuan lebih dalam hal pelayanan, menilai rekan lainya dengan indikator yang sudah disusun dalam buku penilaian. Beberapa ada yang lulus, namun ada juga yang tidak, karena tidak semua checklist pada buku penilaian tersebut berhasil dilakukan.

Pelayanan yang baik terhadap nasabah yang sesuai dengan standar yang ditetapkan oleh manajemen sesungguhnya bergantung pada konsistensi setiap pegawai. Semakin konsisten melakukan, semakin terbiasa dan tidak ada yang luput dilakukan. Namun berdasarkan pengalaman, sering kali pegawai front liners ini lupa, poin-poin apa saja yang harus dilakukan, sebagai contoh lupa mengucapkan customer intimacy seperti "bagaimana kabarnya hari ini Pak/Bu?" dan lain sebagainya. dengan adanya buku penilaian ini, pegawai jadi lebih tau, apa saja kekurangan dari pelayanan yang selama ini diberikan kepada nasabah. Pengetahuan tacit yang berdasarkan pada pengalaman sehari-hari, menjadi lebih teratur dan mudah untuk diingat dan diketahui oleh masingmasing pegawai.

Datang dan perginya nasabah sering kali membuat para pegawai front liners ini merasa bahwa mereka sudah memberikan pelayanan yang sesuai dengan standar pelayanan yang ada, padahal ketika dilihat lagi checklist penilaian yang ada, bisa jadi ada beberapa item yang tertinggal atau tidak dilaksanakan. Di Bank Mandiri, segala pelayanan yang ada memiliki standar pelayanan nya tersendiri, dari waktu antri sampai dengan nasabah dilayani, lalu bagaimana handling complaint yang sesuai untuk setiap permasalahan nasabah, sampai melakukan cross selling produk perbankan yang ada untuk menunjang bisnis perusahaan. Khusus untuk penilaian dari marketing research Indonesia (MRI), semua checklist yang ada harus terpenuhi apabila ingin mendapatkan nilai yang maksimal. Untuk itu, adanya kegiata egrade ini, membantu setiap pegawai untuk lebih aware terhadap kualitas diri sendiri yang sebenarnya dalam melaksanakan standar layanan melalui buku penilaian yang ada. Karena itulah, pegawai yang masih belum bisa melakukan pelayanaan yang mencakup semua checklist yang ada pada buku penilaian, tidak dapat dinyatakan lulus egrade.

Kegiatan egrade sendiri dilakukan bertahap dari case yang paling sederhana sampai yang lebih rumit. Sebagai contoh, pada tahapan awal egrade yang dilakukan teller, teller perlu lulus dalam praktik hitung uang cepat dengan waktu yang telah ditentukan, yaitu kurang dari sepuluh detik untuk menghitung 80 lembar uang kertas. Karena kecepatan adalah salah satu indicator penting kepuasan nasabah terhadap pelayanan di teller. Kenyataan nya, pada praktik nya saat benar-benar melayani nasabah teller tidak konsisten menghitung uang dengan cepat, dengan ada nya egrade ini, yang hasil nya tertuang dalam buku penilaian (explicit knowledge), teller akan lebih mampu mengukur kemampun nya dalam sehari-hari melayani nasabah, dan berbagai contoh lain pelayanan pada tahapan egrade lainnya.

Praktik knowledge sharing dalam berbagai kesempatan yang dilakukan oleh SQO (Service Quality Officer) di Bank Mandiri Cabang Jakarta Cikini, memberikan banyak manfaat dalam rangka pencapaian tujuan bersama cabang tersebut untuk menjadi cabang dengan pelayanan terbaiknya. Berbagai kegiatan ini, adalah strategi komunikasi dari Bapak Arif selaku SQO (Service Quality Officer) dalam rangka pencapaian tujuan tersebut. Adalah sebuah strategi yang efektif, dimana pengetahuan yang ia miliki di bagikan kepada seluruh pegawai dengan berbagai metode yang menyenangkan dan labih mudah. Proses knowledge sharing yang terjadi selaras dengan SECI Model yang dijadikan sebagai pisau bedah pada penelitian ini, sehingga kita dapat mengetahui bersama strageti komunikasi melalui knowledge sharing ini, dan efektivitas nya dalam keberhasilan yang dicapai. 
Tahapan selanjutnya pada SECI Model ialah Combination, mengorganisasikan kumpulan explicit knowledge kedalam satu bentuk media yang lebih sistematis, melalui proses penambahan knowledge baru, kombinasi, dan kategorisasi pengetahuan yang telah terkumpul. Secara lebih sederhana, dapat peneliti simpulkan bahwa tahapan ini adalah proses explicit knowledge menjadi explicit knowledge namun yang lebih terstruktur, dan spesifik.

Rangkaian kegiatan knowledge sharing yang dilakukan pada unit kerja ini, adalah untuk bersama-sama mencapai tujuan organisasi,untuk kaitannya dengan combination, peneliti membahas tahapan ini pada kegiatan evaluation self assessment atau Esas. Dari berbagai pengatahuan yang telah dibagikan kepada seluruh pegawai, pada tahapan esas, pegawai akan dievaluasi, sejauh mana pemahaman nya akan pengatahuan yang selama ini diberikan. Setiap akhir pelaksanaan esas, SQO (Service Quality Officer) memberikan beberapa penjelasan mengenai soal yang dianggap susah atau membingungkan bagi peserta yang mengikuti. Explicit knowledge yang dituangkan dalam pertanyaan-pertanyaan yang terstruktur (karena topik esas setiap bulan nya berbeda-beda, disesuaikan dengan materi yang diberikan sebelumnya via email).

Tentunya untuk lebih memunculkan motivasi, perlu ada nya kompetisi. Hal ini mampu memancing jiwa bersaing yang positif antar pegawai untuk mempu mendapatkan nilai terbaik. Soalsoal esas, biasanya terkait dengan standar layanan dan product knowledge. Dengan adanya persaingan nilai anatara satu dengan yang lain terkait hasil esas, harapannya pegawai akan lebih berusahan dalam mengusai berbagai pengetahuan yang akan di ujikan. Kegiatan ini dapat juga dikatakan sebagai fungsi organisasi, yaitu memotivasi anggota organisasi.

Penguasaan pegawai pada sebuah pengetahuan tentunya memiliki kendala, kendalanya sendiri sebenarnya bukan pada ketidakmampuan pegawai dalam menerimam dan memahami pengetahuan yang diberikan, melainkan perlu sering nya diadakan refreshment guna menyegarkan kembali berbagai pengetahuan yang harus dikuasai. Nasabah yang silih berganti, membawa permasalahan dan kebutuhan yang berbeda-beda, namun umumnya nasabah melakukan transaksi atau kegiatan perbankan lainya yang berupa hal-hal basic, contohnya, di CS hanya mau membuka rekening, mengganti ATM hilang, dan lainnya. Di teller yang rutin terjadi adalah ingin transaksi setoran, tarik tunai, over booking atau justru sepele hanya cetak buku tabungan. Hal tersebut, membuat para frontliners tidak terbiasa dengan product knowledge yang tidak sering ditemui, seperti pengetahuan tentang consumer loan, produk obligasi reksadana, atau bank garansi, padahal pengetahuan akan produk ini sangat harus dikuasai sebagai petugas bank. Untuk itulah refreshment dalam bentuk esas yang rutin dilakukan dua kali dalam sebulan, membantu para pegawai frontliners menguasai hal-hal tersebut.

Tahapan ke-empat atau terakhir pada SECI Model yaitu internalization dimana terjadi transformasi knowledge dari bentuk explicit ke bentuk tacit. Sebagai ilustrasi ialah ketika seorang guru mengajar di dalam kelas, dari bahan pengetahuan buku, disampaikan secara lisan dengan bahasa yang lebih mudah diterima oleh siswa nya. Proses belajar dalam tahapan inikemudian akana diikuti dengan learning by doing yang lambat laun membentuk pengetahuan baru pada individu.

Dari berbagai rangkaian berbagi pengetahuan yang telah didapatkan oelh pegawai, pada sesi tracking lah dapat dilihat secara nyata sejauh mana pegawai frontliners memberikan pelayanan prima kepada nasabah. Seperti telah dijelaskan sebelumnya, tracking tidak hanya dilakukan interen dalam area Cikini, melainkan cross dengan SQO (Service Quality Officer) area lain dan mendapatkan feedback langsung. Tentunya feedback yang diberikan juga berdasarkan standar layanan baku yang telah ditetapkan oleh manajemen namun dikemas dengan bahasa yang lebih friendly dan yang terpenting disesuaikan dengan kebutuhan dan karakteristik nasabah yang berbeda-beda. 
Pengetahuan baik tacit maupun explicit, pada akhirnya akan menjadi bekal bagi seluruh pegawai frontliners dari mulai customer service, teller, hingga security. Pengetahuan yang dimiliki dari berbagai kegiatan knowledge sharing yang dilaksanakan secara konsisten oleh Bapak Arif selaku SQO (Service Quality Officer) Area Cikini, menunjukan hasil yang nyata. Proses demi proses yang ditempuh membuat pegawai yang memiliki bekal pengetahuan yang cukup untuk memberikan pelayan prima kepada nasabah khusunya kepada mystery shopper yang adalah agen dari Marketing Research Indonesia yang memberikan penilaian dan akhirnya menetapkan Bank Mandiri Cabang Jakarta Cikini sebagai cabang dengan pelayanan terbaik pada tahun 2016.

Selanjutnya keseluruhan proses knowledge sharing yang telah dibahas melalui SECI Model akan lebih tajam bila kita tarik benang merah nya pada teori komunikasi organisasi internal yang telah dipaparkan sebelumnya. Komunikasi internal dibagi dalam tiga bentuk yaitu vetikal, horizontal, dan diagonal. Seperti arti harafiah nya, bentuk vertikal adalah bentuk komunikasi yang berlangsung dari atas ke bawah, maupun dari bawah ke atas. Dari berbagai kegiatan knowledge sharing yang dibahas dalam penelitian ini tentunya tergambar bentuk komunikasi ini terbentuk. Pegawai dapat menyampaikan hal-hal yang dianggap sebagai kendala dalam pelayanan terhadap nasabah langsung kepada atasan, agar dapat ditindaklanjuti, begitupun tentunya atasan dapat langsung memberikan arahan kepada bawahan apa yang harus dikerjakan agar tujuan bersama organisasi dapat tercapai, contoh nya pada kegiatan tracking. Selain memberikan evaluasi (downward communication), pegawai juga menyampaikan kendala apa saja yang kerap dialami termasuk kebutuhan-kebutuhan cabang yang perlu dibantu (upward communication). Selanjutnya bentuk horizontal yang tercermin dalam kegiatan knowledge sharing dapt dilihat dari kegiatan Cikini Academy, dimana sesame pegawai tentunya dapat saling bertukar pengalaman (tasit knowledge), tidak ada batas diantaranya, keterbukaan dan kepercayaan dapat terjalin diantaranya. Menarik sekali ketika bentuk diagonal juga dapat tercermin dalam semua kegiatan knowledge sharing yang ada. Tentunya walaupun sesame frontliners antara Teller, Customer Service dan Security adalah divisi yang berbeda, namun semua dapat saling berkomunikasi dan memberikan saran serta kritik yang membangun. Seperti contoh yang ditemui dilapangan, dimana solusi dari kendala yang dihadapai security justru didapat dari rekan customer service. Selain itu, dalam kegiatan Cikini Academy, SQO menghadirkan mentor dari lintas devisi untuk berkomunikasi langsung dengan pegawai dengan berbagai objek pengetahuan. Sungguh kaya.

Strategi komunikasi yang telah dijalan kan oleh SQO pada Bank Mandiri Cabang Jakarta Cikini, menunjukan optimalisasi konsep knowledge sharing dalam konteks komunikasi organisasi internal. Setelah rangakaian penelitian, peneliti menemukan strategi yang diharapkan mampu membuat pegawai lebih memberikan kontribusi lebih terhadap tujuan dalam organisasi. Strategi yang dimaksud ialah menumbuhkan suasana kompetensi dalam lingkup kerja pegawai yang disadari maupun tidak memacu setiap individu memberikan kinerja yang lebih agar mampu bersaing dengan individu yang lain. Kemampuan bersaing juga bukan berarti tanpa dibekali, strategi juga harus memiliki persiapan, dalam organisasi ini telah terbentuk komunikasi kelompok kecil maupun kelompok besar dalam setiap kegiatan knowledge sharing yang diselenggarakan, optimalisasi kelompok kecil dan besar ini menjadi cara agar strategi ini dapat menghasilkan output yang maksimal. Tentunya komunikasi dalam kelompok ini sejalan dengan konteks komunikasi organisasi internal. Selain dari strategi yang ditemukan, peneliti mencoba menawarkan model strategi yang diharapkan mampu menunjang organisasi. Dalam klasifikasi komunikasi internal telah dijelaskan bahwa ada komunikasi persona dan komunikasi kelompok, kelompok juga terdiri dari kelompok besar dan kelompok kecil. Untuk mengoptimalisasikan klasifikasi yang sudah ada dalam organisasi 
ini, peneliti mencoba menawarkan model distribusi pesan yang lebih efisien. Tentunya dalam setiap kali tatap muka yang diadakan oleh SQO (Service Quality Officer), menyita waktu dan tenaga pegawai, padahal kegiatan yang diadakan memberikan manfaat yang besar bagi pegawai tersebut. Potensi ketidak hadiran pun ada, serta kondisi fisik yang bisa jadi tidak mendukung untuk pulang kerja lebih larut (sedang hamil misalnya). Strategi komunikasi dalam konsep knowledge sharing dapat terus berjalan dan dirasakan manfaat nya, namun dalam proses distribusi pesan atau informasi yang lebih inovatif. Seperti optimalisasi kelompok kecil, pertemuan dapat diambil pada waktu pagi hari sebelum jam layanan dengan durasi waktu yang lebih singkat, contohnya. Selain itu, optimalisasi bentuk komunikasi horizontal dapat dijadikan strategi komunikasi baru dalam pencapaian tujuan organisasi, adanya kelompok kecil dari setiap divisi yang berbagi wilayah tanggung jawab nya dalam memberikan masukan dalam perspektif umum, jadi feedback yang diterima lebih kaya

\section{KESIMPULAN}

Strategi komunikasi yang diambil Bank Mandiri Cikini adalah membuat kegiatan-kegiatan yang positif dalam kerangka knowledge sharing, yaitu Esas, Egrade, Cluster Forum dan Tracking, yang dilakukan secara konsisten agar seluruh pegawai mengerti dan memahami serta melaksanakan pengetahuan-pengetahuan baik tacit maupun explicit agar dapat memenangkan cabang dengan pelayanan terbaik. Proses knowledge sharing ini dapat dikatakan mampu mengantarkan Bank Mandiri Cabang Jakarta Cikini sukses menadapat gelar Best Branch in Srvice Excellent di tahun 2016 ini. Hal ini karena dalam rangkaian proses penilaian, SQO (Service Quality Officer) menyiapkan seluruh pegawai nya agar mampu menghadapi survey pelanggan yang dilakukan oleh Marketing Research Indonesia dengan baik, yaitu dengan dibekali pengetahuan yang cukup dalam melayani nasabah sesuai dengan standar pelayanan yang ada namun tetatp fleksibel dan memberikan kenyamanan serta kepuasan terhadap nasabah.

\section{Daftar Pustaka}

Effendy, Onong Uchjana. 1990. Ilmu Komunikasi : Teori dan Praktek. Bandung: PT. Remaja Rosdakarya.

Miles, Mattew, dan Huberman A.M, 1992. Analisis Data Kualitatif. UI Press, Jakarta.

Moleong, Lexy, 2010. Metodologi Penelitian Kualitatif. Cetakan Ke duapuluh delapan, Rosa . Bandung.

Morissan , 2013. Teori Komunikasi. Ghalia Indonesia., Jakarta.

Mulyana, Dedi, 2009. Ilmu Komunikasi Suatu Pengantar. Cetakan ke tigabelas. Rosdakarya, Bandung.

Nonaka, I. \& Takeuchi, H. 1995. The Knowledge-creating company: how Japanese companies create the dynamics of innovation. New York : Oxford University Press.

Polanyi , M (1974). Personal Knowledge :Towards a Post-Critical Philosophy. Chicago, IL : University of Chicago Press. (karya asli terbit 1958)

Raharso, Sri \& Sri Surjani Tjahjawati, 2016. Organisasi Berbasis Pengetahuan Melalui Knowledge Sharing. ALFABETA, Bandung.

Robbins, P Stephen, 1996. Perilaku Organisasi. Edisi Bahasa Indonesia Jilid I dan II, PT Prinhalindo Indonesia, Jakarta.

Ruliana, Poppy, 2014. Komunikasi Organisasi , Teori dan Studi Kasus. PT RajaGrafindo Shella Gusti Suwawa.Persada, Jakarta. 
R. Wayne Face \&Don F Faules. 2010. Komunikasi Organisasi - Strategi Meningkatkan KinerjaPerusahaan . Cetakan ke tujuh. PT Remaja Rosdakarya, Bandung.

Sobirin, Achmad, 2007. Budaya Organisasi, Pengertian, Makna dan Aplikasinya dalam Kehidupan Organisasi. UPP STIM YKPN, Jakarta.

Thoha, Miftah, 1998. Perilaku Organisasi Konsep Dasar dan Aplikasinya. Raja Grafindo Persada, Jakarta.

Wursanto, Ignasius. 2005. Dasar-Dasar Ilmu Komunikasi. Yogyakarta: CV Andi Offset. 